Vol.: 6 Issue: 3 Year: 2018, pp. 379-392

Citation: Kılıç Akıncı S. (2018), Testing Mediating Effect Of Individual Exchange Ideology On Distributive Justice And Work Engagement Relationship In A Collectivist Society, BMIJ, (2018), 6(3): 379-392 doi: http://dx.doi.org/10.15295/bmij.v6i3.365

\title{
TESTING MEDIATING EFFECT OF INDIVIDUAL EXCHANGE IDEOLOGY ON DISTRIBUTIVE JUSTICE AND WORK ENGAGEMENT RELATIONSHIP IN A COLLECTIVIST SOCIETY ${ }^{1}$
}

Sevcan KILIÇ AKINCI ${ }^{2}$

\author{
Received Date (Başvuru Tarihi): 01/11/2018 \\ Accepted Date (Kabul Tarihi): 15/11/2018 \\ Published Date (Yayın Tarihi): 30/11/2018
}

\begin{abstract}
This study aims to test the Social Exchange Theory in a collectivist society and extends it by examining the link between distributive justice (DJ) and work engagement (WE). Specifically, individual exchange ideology (IEI) is integrated into the relationship, and it establishes if exchange ideology mediates between the relationships. The study was conducted on a large sample (499) of Turkish blue and white-collar employees from business units of 15 independent companies; 10 different industry types and data was analysed with Structural Equation Modelling. The findings of this research supported the previous findings about DJ's positive relationship with WE. Secondly, findings showed that IEI acted as a mediator between DJ and WE, and it mediated 24\% of the effect of DJ's on WE. Results revealed that employees reciprocated perceived justice (DJ in our case) by engaging themselves more in their work, to meet organisational goals, but this increases with the effect of individual exchange ideology; and therefore, supported the applicability of Social Exchange Theory in a collectivist society, namely in a Turkish context.
\end{abstract}

Keywords: Work Engagement, Individual Exchange Ideology, Distributive Justice, Turkey

JEL Codes: M10, J28, J24

\section{DAĞITIMSAL ADALET VE İŞE ADANMA İLIŞKISSINDE BİREYSEL DEĞISŢiM IDEOLOJISININ ARACILIK ETKISINININ KOLLEKTIVIST BIR TOPLUMDA TEST EDILMESI}

ÖZ

Bu çalışma, Sosyal Mübadele Teorisi'ni kollektivist bir toplumda test etmekte ve dağıtımsal adalet ile işe adanma arasındaki ilişkiyi inceleyerek teoriye katkı sunmaktadır. Bu ilişskiye bireysel mübadele ideolojisi değisşeni eklenerek, aracllık etkisi olup olmadı̆̆ araş̧tırlmıştır. Çalış̧ma 10 farklı endüstride faaliyet gösteren 15 işletmeden beyaz ve mavi yakalı toplam 499 çalışanı kapsayan geniş bir örneklem üzerinde test edilmiş ve veriler Yapısal Eşitlik Modellemesi ile analiz edilmiştir. Çalışmanın bulguları ilk olarak dağıtımsal adalet ile işe adanma arasında pozitif bir ilişski olduğunu göstermiştir ve bu yönüyle litaratürdeki çalışmalarla uyumludur. Bulgular ikinci olarak, dağıtımsal adalet ile işe adanma iliş̧kisinde bireysel mübadele ideolojisi değişkeninin aracılık etkisi yaptığını (\% 24) göstermiştir. Sonuçlar çalı̧̧anların dağıtımsal adaletin uygulanması karşısında örgütsel amaçları gerçekleştirmek üzere işe daha fazla adandıkların ve bunu artıran değişkenin bireysel mübadele ideolojisi değişkeni olduğunu göstermişstir. Bu bağlamda, Sosyal Mübadele Teorisinin kollektivist bir ülke olan Türkiye'deki bir örneklem üzerinde geçerli olduğu ispatlanmıştır.

Anahtar Kelimeler : İșe adanma, Bireysel Değişim İdeolojisi, Dağttımsal Adalet, Türkiye

JEL Kodlart: M10, J28, J24

\footnotetext{
${ }^{1}$ This research paper is the extended version of the study titled "Mediating Effect of Individual Exchange Ideology on Distributive Justice and Work Engagement In a Collectivist Society", which was orally presented in Business and Research Conference held in Safranbolu, Turkey between 12-14 September 2018.

${ }^{2}$ Faculty Member, PhD. Erzurum Technical University, sevcan.akinci@erzurum.edu.tr https://orcid.org/0000-0003-3315-6346
} 


\section{INTRODUCTION}

In today's highly competitive work environment, a very significant way of achieving competitive advantage over rivals is ensuring employee engagement. Companies spend over $\$ 720$ million each year on employee engagement, and that's projected to rise to over $\$ 1.5$ billion in future (La Motte, 2015).

While exchange ideology has been offered as a possible reason individuals choose to engage in their work (Saks, 2006) with varying degrees, there has been no specific investigation of the role of individual exchange ideology and its influence on distributive justice and as a means to impact engagement levels in the Turkish context. Our study tests distributive justice's effect on work engagement (WE) to establish if individual exchange ideology mediates this relationship.

Individual exchange ideology is a continuum (Eisenberger et al., 1986) and can be described as the degree to which an individual's work effort is contingent upon perceived organisational treatment (Eisenberger et al., 1986; Witt, 1991; Witt \& Broach, 1993). At one end of its dispositionalcontinuum, employee effort is based on organisation reinforcements - a strong exchange ideology. At the other end of the continuum, employees put forth effort without regard to what they receive from the organisation - a weak exchange ideology (Witt \& Broach, 1993). In short, individuals with a strong exchange orientation are more likely to return a good deed than those with a low exchange orientation (Cropanzano \& Mitchell, 2005). Individuals with a low exchange orientation are not influenced as much by reciprocity beliefs and therefore would exert the same effort regardless of the organisation's actions (Hastings, 2011).

Specifically, this study aims to examine whether exchange ideology can be an intermediate mechanism through which DJ affects work engagement. We make two specific contributions to the literature. Firstly, we propose and test the hypothesis that DJ has a direct positive relationship with WE. Secondly, this is the first study to examine the mediation effect of individual exchange ideology on work engagement in the Turkish context. Thirdly, by analysing the links between these variables, our study extends the Social Exchange Theory (SET). Lastly, as a methodological contribution, we tested our model by using Omega besides Cronbach alpha.

\section{LITERATURE REVIEW}

\subsection{Work Engagement}

In the academic literature, work engagement is often defined and conceptualized as the amount of discretionary effort exhibited by employees in their jobs (Frank et al., 2004) or emotional and intellectual commitment to the organization (Baumruk, 2004; Richman, 2006; Shaw, 2005) and 'harnessing of organisational members' selves to their work roles' (Kahn, 1990). As a motivational- 
psychological state, work engagement is a response or reaction to one's work (Meyer et al., 2010; Schaufeli \& Bakker, 2010; Schaufeli et al., 2006), and is a combination of the capability to work (energy, vigour) and the willingness to work (involvement, dedication) (Van Bogaert et al., 2013).

Engaged personnel employ and express themselves physically, cognitively, and emotionally during role performances. In other words, it is a positive, fulfilling, affective-motivational state of work-related well-being (Bakker \& Schaufeli, 2008). Saks (2006), proved that engagement (both job and organisation engagement) mediate the relationships between the antecedents (organisational support, job characteristics and procedural justice) and consequences (job satisfaction, organisational commitment, intentions to quit, and organizational citizenship behaviour) of engagement.

In the academic literature, typically "employee engagement" and "work engagement" are used interchangeably. EE, which refers to a positive attitude held by the employee toward the organisation and its values, suggests that the human resource of the organisation will become engaged with their work and devote their complete self to the role in the organisation, through investing intellectual effort, experiencing positive emotions and meaningful connections with others (Alfes et al., 2012), when antecedents are in place that signal to employees that they are valued and trusted (Rich et al., 2010; Saks, 2006).

Shuck (2011) suggested four major approaches for employee engagement frameworks from the academic perspective: (1) Kahn's (1990) need-satisfying approach, (2) Maslach et al. (2001), burnout-antithesis approach, (3) Harter et al.'s (2002) satisfaction-engagement approach, and (4) Saks's (2006) multidimensional approach. For explaining employee engagement, Social Exchange Theory is recommended as a stronger theoretical rationale and frequently referred to in academic research.

\subsection{Social Exchange Theory}

The antecedents or conditions of engagement in both Kahn's (1990) and Maslach et al.'s (2001) model can be regarded as economic and socioemotional exchange resources. Employees who receive these resources from their organisation feel obliged to repay the organisation with differing levels of engagement. According to Saks (2006), although Kahn's (1990) and Maslach et al.'s (2001) models show the importance of the conditions or antecedents that are necessary for engagement, they do not fully explain why individuals will respond to these conditions with varying degrees of engagement. Social Exchange Theory (SET) is one of the main research streams and is considered to be one of the most influential conceptual paradigms for understanding workplace behaviour (Cropanzano \& Mitchell, 2005) as it provides a theoretical foundation to explain why employees choose to become more or less engaged in their work and organisation, which is also recommended by Saks (2006). 
Saks (2006) proved that engagement (both job and organisation engagement) mediate the relationships between the antecedents (organisational support, job characteristics and procedural justice) and consequences (job satisfaction, organisational commitment, intentions to quit, and organisational citizenship behaviour) of engagement.

\subsection{Individual Exchange Ideology}

As widely accepted, employees' reactions to treatment done by their organisation are guided by reciprocity norms which is a generalised moral norm defining certain actions and obligations as repayments for benefits received (Gouldner, 1960).

When employees perceived that the organisation supported them, the reciprocity norm would obligate them to support the organisation (Gouldner, 1960). Eisenberger et al. (1986) developed a measure to assess how sensitive employees were to reciprocity obligations, focusing in particular on their beliefs that work effort should depend on treatment by the organisation. Individual exchange ideology (IEI) is a continuum (Eisenberger et al., 1986) and can be described as the degree to which an individual's work effort is contingent upon perceived organisational treatment (Eisenberger et al., 1986; Witt, 1991; Witt \& Broach, 1993). At one end of its dispositional-continuum, employee effort is based on organisation reinforcements - a strong IEI. At the other end of the continuum, employees put forth effort without regard to what they receive from the organisation - a weak EI (Witt \& Broach, 1993).

First studies on IEI imply that those with a strong IEI have self-serving bias and focus more on the self than on others (Pazy \& Ganzach, 2010; Xiao et al., 2017). Individuals with a high exchange orientation strongly adhere to the norm of reciprocity and, therefore, carefully track obligations, keep score within interactions, expect direct and immediate giving, are sensitive and responsive to injustice and unfair treatment, monitor input and output closely in relationships, view exchange partners as debtors, limit knowledge sharing, and are more likely to perceive unfairness and to feel they are being taken advantage of within a relationship (Coyle-Shapiro \& Neuman, 2004; Cropanzano \& Mitchell, 2005; Cureton, 2014; Eisenberger et al., 1986; Lin, 2007; Molm \& Takahashi, 2018; Redman \& Snape, 2005; Takeuchi et al., 2011).

In short, individuals with a strong exchange orientation are more likely to return a good deed than those with a low exchange orientation (Cropanzano \& Mitchell, 2005). Individuals with a low exchange orientation are not influenced as much by reciprocity beliefs and therefore would exert the same effort regardless of the organisation's actions (Hastings, 2011). Since they are less likely to care if exchanges are not reciprocated, they are more open-minded and agreeable, and have a higher propensity to trust others (Cropanzano \& Mitchell, 2005; Cureton, 2014; Takeuchi et al., 2011) and 
will "continue to work hard even if they perceive themselves to be poorly or unfairly treated" (CoyleShapiro \& Neuman, 2004; Cureton, 2014; Witt, 1991; Witt \& Broach, 1993).

Since then, research has found that individual exchange ideology (IEI) predicted positive outcomes such as organisational citizenship (Hastings, 2011), satisfaction and commitment (Pazy \& Ganzach, 2010; Witt et al., 2001). Researches on IEI show that IEI moderates antecedents and consequences of engagement in specific; and positive outcomes for the organisation in general as such it moderates between perceived organisational support and organisational citizenship behaviours (Ladd \& Henry, 2000), perceived organisational support and work effort (Orpen, 1994), and procedural justice perceptions and satisfaction with training (Witt \& Broach, 1993), employees' perceptions of work environment and their organisational citizenship behaviours (Witt, 1991) and procedural justice and (Witt et al., 2001) perceived organisational support and reduced absenteeism (Eisenberger et al., 1986).

IEI is also reported to be effective in the procedural justice perceptions and satisfaction with training (Witt \& Broach, 1993). Scott and Colquitt (2007) found that IEI moderated the relationships between various forms of justice and withdrawal, organisational citizenship behaviour and performance. An important finding of the study to note is, IEI was found as a more useful moderator than either Equity Sensitivity or the Big Five personality factors.

The effects of IEI on positive outcomes for an organisation which are similar to engagement, such as commitment, and satisfaction are also reported in the academic literature. Pazy and Ganzach (2010), reported that IEI had effects on both initial and long-term committed behaviour; and these effects were stronger than those of pre-entry perceived organisational support. Exchange beliefs also moderate the relationship between participative decision-making and acceptance of group norms and satisfaction with promotion opportunities (Witt, 1992). An important finding is the relationship between individual EI and satisfaction levels. As such Takeuchi, Takeuchi et al. (2007) reported people with high exchange ideology tend to be less satisfied with their work, and Witt et al. (2001) reported IEI significantly increased manager-rated commitment. Similarly, Witt and Broach (1993), reported that strong IEI significantly increased satisfaction with training, and knowledge sharing (Eisenberger et al., 2001; Sinclair \& Tetrick, 1995; Xiao et al., 2017).

Following previous research (Witt \& Broach, 1993), this study considers IEI as a reflection of an individual's expectation for person-organisation exchange. From this perspective, in this study, individual exchange ideology's mediating role between distributive justice and WE is researched. 


\subsection{Distributive Justice}

Justice, fairness and equity which are used interchangeably are core values in organisations (Konovsky, 2000). Justice refers to perceptions of employees about fair treatment received from an organization and their behavioral reaction to such perceptions (Ghosh et al., 2014).

Organizational justice consists of three kinds, one of which is distributive justice. Distributive justice is defined and conceptualized as the fairness of distribution of resources or about results orientations. According to an estimation, fairness was not dependent upon the fixed level of results. However, it depended upon the social assessment of input with financial and social reward output ratios (Alvi \& Abbasi, 2012). Based on Adam's (1965) Equity Theory, distributive justice is said to exist when the distribution of outcomes such as compensation, benefits, and other rewards meet employees' expectations vis-à-vis their inputs (Chou, 2009; Clay-Warner et al., 2005; Ghosh et al., 2014; Simpson \& Kaminski, 2007).

When employees have a high perception of justice in their organisation, they are more likely to be fair in their roles by giving more of themselves through higher levels of engagement (Saks, 2006).

\subsection{Previous Research}

In the academic literature, employee engagement has attracted considerable interest over the years since the vast majority of the researchers found evidence that employees' level of engagement predicts positive outcomes for an organisation and as documented by Harter et al. (2002). Employee satisfaction and engagement are related to meaningful business outcomes at a magnitude that is important to many organisations. Most importantly, engaged employees are more likely to exhibit discretionary efforts and improve individual performance (Corporate Leadership Council, 2004). Similar results are obtained by Schaufeli et al. (2002), Bamford et al. (2013), Brunetto et al. (2013), Fiabane et al. (2013), Jenaro et al. (2011), Othman and Nasurdin (2013), Rickard et al. (2012), Van Bogaert et al. (2013), Garrosa et al. (2011), Lawrence (2011), Lu et al. (2011), Palmer (2011), Tomic and Tomic (2011), Walker and Campbell (2013) and Cureton (2014).

Saks (2006) proved that engagement (job and organisation engagement) mediate the relationships between the antecedents (organisational support, job characteristic, and procedural justice) and consequences (job satisfaction, organisational commitment, intentions to quit, and organisational citizenship behaviour) of engagement.

When we come to the effect of perception of equity on engagement, we see that nearly all of the studies in the academic literature agree that when employees have a high perception of justice in their organisation, they are more likely to be fair in their roles by giving more of themselves through higher levels of engagement as Saks (2006) stated. Saks (2006) also proved that distributive justice is positively linked with employee engagement. 
Rich et al. (2010) reported that engagement mediates relationships between value congruence, perceived organisational support, and core self-evaluations, and two job performance dimensions: task performance and organisational citizenship behaviour. Alvi and Abbasi (2012) also reported that distributive justice was positively related with EE. Ghosh et al. (2014) examined if perceptions of distributive, procedural and interactional justice are related to employee engagement, as an extension of the antecedents-consequences model of Saks (2006), and found that distributive and interactional justice took precedence over procedural justice in determining job engagement, while distributive justice played the most important role in determining organisational engagement, followed by procedural and interactional justice. Prominent studies (Ghosh et al., 2014; Sze \& Angeline, 2011) reported that distributive justice takes precedence over procedural justice in determining work engagement to be the most crucial part of equity perception among employees.

When we come to the mediation effect of individual exchange ideology on, WE, which is a very new topic in the academic literature, we see that studies on this topic are really scarce; though nearly all of the studies report the existence of the mediation effect of EI on the relationship between justice perceptions and with both satisfaction and engagement. Witt and Broach (1993) reported that perceptions of procedural justice accounted for greater variance in satisfaction among trainees with a strong exchange ideology than among those with a weak exchange ideology. In a recent study Sze and Angeline (2011) reported that in Malaysia, employees' perceptions of supervisor support, distributive justice, procedural justice, and participation in decision-making were positively and significantly related to their job engagement. They also showed that the relationships between employees' perceptions of supervisor support and job engagement, as well as between employees' participation in decision-making and job engagement were stronger when their EI was high. Similarly Cureton's (2014) study on the role of individual exchange ideology in co-worker social support and work engagement levels revealed positive relationships between co-worker social support and work engagement, while a negative relationship was found between EI, co-worker social support, and work engagement. When the effects of EI are controlled or held constant across the remaining two variables, the correlation between work engagement and co-worker social support was found to be lower. Sze and Angeline (2011), reported that perceptions of supervisor support, distributive justice, procedural justice, and participation in decision-making are related to their job engagement; and exchange ideology moderates between the relationships. Unlike procedural justice, the relationship between distributive justice and job engagement was stronger, when employees had high, rather than low exchange ideology.

For the Turkish setting, no research has yet been conducted on the effect of individual exchange ideology in DJ and WE relationship. 


\section{MATERIALS AND METHOD}

The Aim of the Study

In this study, drawing from SET, we develop and test a model where DJ was linked to WE, and we integrated and tested the mediation effect of EI in this relationship. Empirical support for this model was offered, and its potential implications for research and practice were discussed.

\subsection{Model and Hypothesis}

The mediating effect of EI on WE is a very new topic in the academic literature and research on the role of IEI between DJ on WE is scarce. In light of the literature review, our paper proposes that DJ is related to WE and exchange ideology mediates this relationship and below hypotheses were tested.

Nearly all of the studies in the academic literature agree that when employees have a high perception of justice in their organisation, they are more likely to be fair in their roles by giving more of themselves through higher levels of engagement as Saks (2006) stated. It is also reported in recent studies that distributive justice is positively linked with employee engagement (Alvi \& Abbasi, 2012; Biswas et al., 2013; Ghosh et al., 2014; Saks, 2006; Sze \& Angeline, 2011; Wayne et al., 1997).

Therefore, our first hypothesis is formulated as:

Hypothesis 1 : Distributive justice is (positively) related to work engagement.

According to Molm (1994), interdependence, which involves mutual and complementary arrangements, is considered as a defining characteristic of social exchange. Social exchange generates obligations through a series of interactions between the parties who are in a state of reciprocal interdependence, and individuals with a strong IEI are more likely to feel obliged to reciprocate the benefit (Cropanzano \& Mitchell, 2005; Eisenberger et al., 1986; Saks, 2006). Eisenberger et al. (2001) stated, “employee EI concerns employees' application of the reciprocity norm to their relationship with the work organisation". While exchange ideology has been offered as a possible reason individuals choose to engage in their work (Saks, 2006) with varying degrees, there has been no specific investigation of the role of individual exchange ideology and its influence on distributive justice and as a means to impact engagement levels in the Turkish context.

Therefore, our second hypothesis was formulated as below:

Hypothesis 2 : Individual Exchange Ideology mediates the relationship between DJ and WE.

Saks (2006) recommended further research to test individual variables on the relationships between antecedents and consequences of WE. Although previous research documents supported evidence that DJ positively influences, WE, it is still necessary to increase our understanding of engagement in different work environments by examining the link between DJ and WE. 


\subsection{Sample and Data Collection}

As a sample from the Turkish setting, we tested the model on a large sample of Turkish blue and white-collar employees from business units of 15 independent companies; 10 different industry types on employees with different demographics. For this research, 560 self-administered questionnaires were sent to employees in business. Participation in our survey was voluntary, no remuneration was offered, and participants were informed that their responses would remain anonymous and confidential. After deleting cases with the missing values, the final sample consisted of 499 individuals. Data were collected through the method of convenience sampling and at one time. The final study sample $(\mathrm{N}=499)$ consisted of 307 men, and 192 women, and the mean age of the sample was 30. This is because female employees are still rare in the industry. The mean tenure of the sample was 7,2 years. Regarding educational background, 30\% had a high school degree, $19 \%$ of the sample had an associate degree; $48 \%$ had an undergraduate degree, and $3 \%$ had a master degree.

\subsection{Data Analysis and Findings}

The study was conducted on a large sample (499) of Turkish blue and white-collar employees. Data were analysed with Structural Equation Modelling. To analyze the data, R-Project program (R Core Team, 2018), Psych package (Revelle, 2018) and lavaan package (Rosseel, 2012) was used.

Firstly, an iterative "item trimming" procedure was performed for the original scale items and following that total Omega was calculated as 0,96. As a first step, the direct effect of DJ over WE was tested. For model fit SRMR value was calculated as 0,043 and NFI value as 0,935; both of which proved that the model was acceptable. The path coefficient of DJ's direct effect over WE was found significant $(0,420)$ as shown in Figure 1. It showed that distributive justice (DJ) was (positively) related to WE and our first hypothesis was adopted, which is similar to the findings in the academic literature.

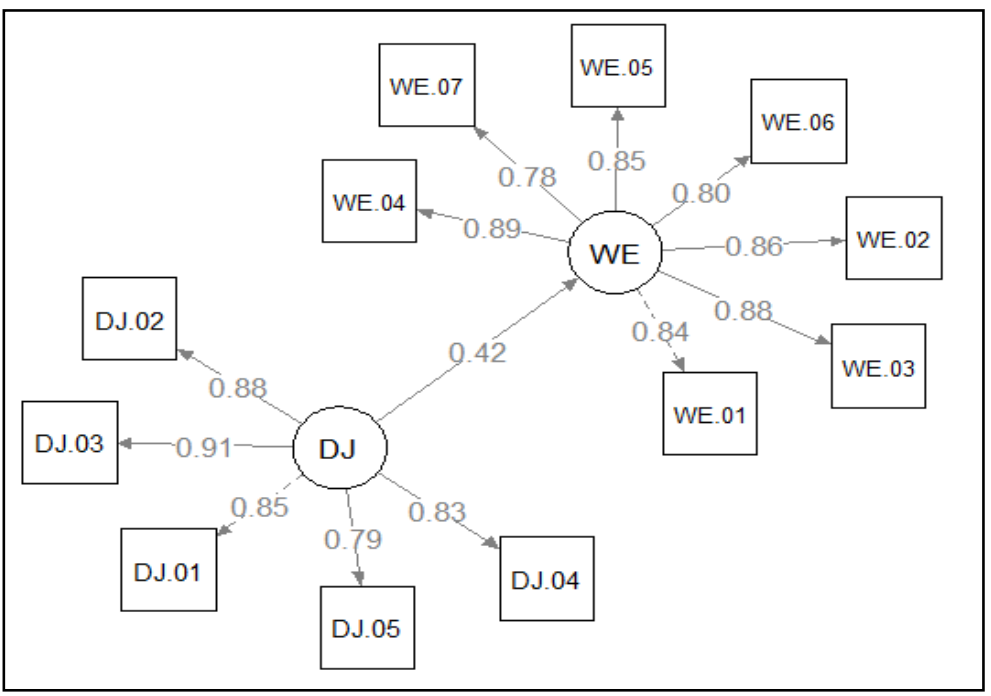

Figure 1. DJ's direct effect on WE. 
To research the mediation effect of IEI, IEI was added to the model as a/the mediator, and the model was found to be acceptable with SRMR value 0,041 and NFI values 0,963. The path coefficient of IEI's direct effect over WE was found to be significant (0,36 with p-value: 0,000$)$. The path coefficient of DJ's direct effect over IEI was found to be significant $(0,30$ with p-value: 0,000$)$ as shown in Figure 2.

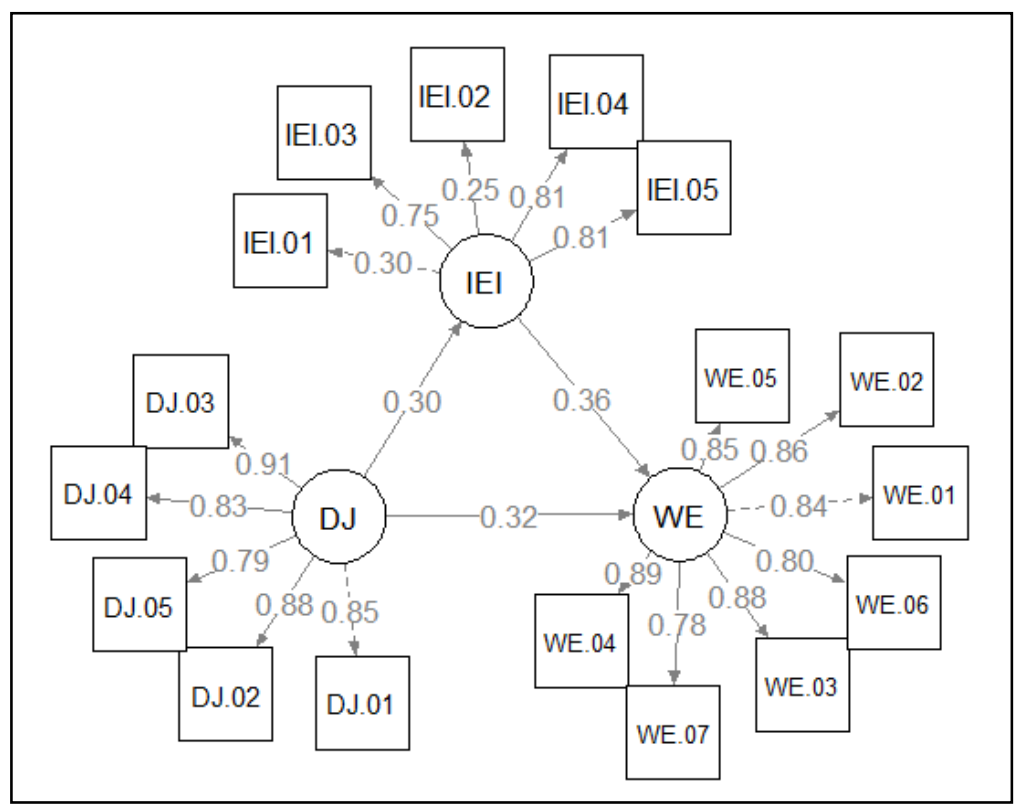

Figure 2. IEI's mediation effect on the relationship of DJ and WE.

Consequently, it was found that distributive justice (DJ) was (positively) related to WE, which is similar to the findings in the academic literature.

It was also found that EI acts as a mediator (24\%) between DJ and WE, and it mediated the effect of DJ's on WE. Therefore, our second hypothesis was also adopted.

\section{CONCLUSION}

The paper makes a contribution to the literature by extending empirical research on SET and its applications in a non-U.S. environment, and therefore, highlighting the increased importance of context in organisational science research today. The role of IEI on the relationship between DJ and WE is a very new topic in the academic literature and studies on this relationship are instead scarce in general, and in particular it is not yet tested in the Turkish context. Testing the mediating effect of IEI in the relationship of DJ with WE contribute to the limited research in the Turkish context.

Grounded on SET, these results revealed that distributive justice (DJ) was (positively) related to WE and our first hypothesis was adopted, which is similar to the findings in the academic literature. This shows that when employees have a high perception of justice in their organisation, they are more likely to be fair in their roles by giving more of themselves through higher levels of engagement. 
As a motivational-psychological state, work engagement is a response or reaction to one's work (Meyer et al., 2010; Schaufeli \& Bakker, 2010; Schaufeli et al., 2006), and is a combination of the capability to work (energy, vigour) and the willingness to work (involvement, dedication) (Van Bogaert et al., 2013), which increases with distributive justice in organisations.

It was also found that IEI acted as a mediator (24\%) between DJ and WE, and it mediated the effect of DJ's on WE. Therefore, our second hypothesis was also adopted. Results revealed that employees reciprocated perceived justice (DJ in our case) by engaging themselves more in their work, to meet organisational goals and devote their complete self to a role in the organisation.

Individual exchange ideology is a continuum (Eisenberger et al., 1986) and can be described as the degree to which an individual's work effort is contingent upon perceived organisational treatment (Eisenberger et al., 1986; Witt, 1991; Witt \& Broach, 1993).

The results confirmed the applicability of Social Exchange Theory in a collectivist society in Turkey and advocates that employees who perceive that there is distributive equity in the organisation are more likely to have strong bonds with the work and repay this to the organisation through higher levels of engagement. 


\section{REFERENCES}

Adams, J. S. (1965). Inequity in Social Exchange. Advances in Experimental Social Psychology, 2, $267-299$. https://doi.org/10.1016/S0065-2601(08)60108-2

Alfes, K., Shantz, A., \& Truss, C. (2012). The Link Between Perceived HRM Practices, Performance and Well-Being: The Moderating Effect of Trust in the Employer. Human Resource Management Journal, 22(4), 409-427. https://doi.org/10.1111/1748-8583.12005

Alvi, A. K., \& Abbasi, A. S. (2012). Impact of Organizational Justice on Employee Engagement in Banking Sector of Pakistan. Middle-East Journal of Scientific Research, $12(5), \quad 643-649$. https://doi.org/10.5829/idosi.mejsr.2012.12.5.1725

Bakker, A. B., \& Schaufeli, W. B. (2008). Positive Organizational Behavior: Engaged Employees in Flourishing Organizations. Journal of Organizational Behavior, 29(2), 147-154. https://doi.org/doi:10.1002/job.515

Bamford, M., Wong, C. A., \& Laschinger, H. (2013). The Influence of Authentic Leadership and Areas of Worklife on Work Engagement of Registered Nurses. Journal of Nursing Management, 21(3), 529-540. https://doi.org/doi:10.1111/j.1365-2834.2012.01399.x

Baumruk, R. (2004). The Missing Link: The Role of Employee Engagement in Business Success. Workspan; ABI/ INFORM, 47, 48-52. https://doi.org/10.1007/s13398-014-0173-7.2

Biswas, S., Varma, A., \& Ramaswami, A. (2013). Linking distributive and procedural justice to employee engagement through social exchange: A field study in India. International Journal of Human Resource Management. https://doi.org/10.1080/09585192.2012.725072

Brunetto, Y., Xerri, M., Shriberg, A., Farr-Wharton, R., Shacklock, K., Newman, S., \& Dienger, J. (2013). The Impact of Workplace Relationships on Engagement, Well-Being, Commitment and Turnover for Nurses in Australia and the USA. Journal of Advanced Nursing, 69(12), 2786-2799. https://doi.org/10.1111/jan.12165

Chou, R. J.-A. (2009). Organizational Justice and Turnover Intention: A Study of Direct Care Workers in Assisted Living Facilities for Older Adults in the United States. Social Development Issues, 31(1), 69-85. Retrieved from http://search.ebscohost.com/login.aspx?direct=true\&db=edo\&AN=36978873\&site=eds-live

Clay-Warner, J., Hegtvedt, K. A., \& Roman, P. (2005). Procedural Justice, Distributive Justice: How Experiences with Downsizing Condition Their Impact on Organizational Commitment. Social Psychology Quarterly, 68(1), 89102. https://doi.org/http://dx.doi.org/10.1177/019027250506800107

Corporate Leadership Council. (2004). Driving Performance and Retention Through Employee Engagement A Quantitative Analysis of Effective Engagement Strategies. Washington, DC, US. Retrieved from http://www.academia.edu/download/33187063/Employee_engagement.pdf

Coyle-Shapiro, J. A.-M., \& Neuman, J. H. (2004). The Psychological Contract and Individual Differences: The Role of Exchange and Creditor Ideologies. Journal of Vocational Behavior, 64(1), 150-164. https://doi.org/10.1016/S0001-8791(03)00031-9

Cropanzano, R., \& Mitchell, M. S. (2005). Social Exchange Theory: An Interdisciplinary Review. Journal of Management, 31(6), 874-900. https://doi.org/10.1177/0149206305279602

Cureton, S. S. (2014). The Role of Exchange Ideology in Coworker Social Support and Work Engagement. The University of Southern Mississippi, Hattiesburg, Mississippi, US. Retrieved from https://aquila.usm.edu/dissertations/15

Eisenberger, R., Armeli, S., Rexwinkel, B., Lynch, P. D., \& Rhoades, L. (2001). Reciprocation of Perceived Organizational Support. Journal of Applied Psychology. US: American Psychological Association. https://doi.org/10.1037/00219010.86.1.42

Eisenberger, R., Huntington, R., Hutchison, S., \& Sowa, D. (1986). Perceived Organizational Support. Journal of Applied Psychology, 71(3), 500-507. https://doi.org/10.1037/0021-9010.71.3.500

Fiabane, E., Giorgi, I., Sguazzin, C., \& Argentero, P. (2013). Work Engagement and Occupational Stress in Nurses and Other Healthcare Workers: The Role of Organisational and Personal Factors. Journal of Clinical Nursing, 22(1718), 2614-2624. https://doi.org/doi:10.1111/jocn.12084

Frank, F., Finnegan, R., \& Taylor, C. (2004). The Race for Talent: Retaining and Engaging Workers in the 21 st Century. Human Resource Planning, 27(3), 12-25.

Garrosa, E., Moreno-Jiménez, B., Rodríguez-Muñoz, A., \& Rodríguez-Carvajal, R. (2011). Role stress and personal resources in nursing: A cross-sectional study of burnout and engagement. International Journal of Nursing Studies, 48(4), 479-489. https://doi.org/10.1016/J.IJNURSTU.2010.08.004

Ghosh, P., Rai, A., \& Sinha, A. (2014). Organizational Justice and Employee Engagement. Personnel Review, 43(4), 628652. https://doi.org/10.1108/PR-08-2013-0148

Gouldner, A. W. (1960). The Norm of Reciprocity: A Preliminary Statement. American Sociological Review, 25(2), 161178. https://doi.org/10.2307/2092623

Harter, J. K., Schmidt, F. L., \& Hayes, T. L. (2002). Business-Unit-Level Relationship between Employee Satisfaction, Employee Engagement, and Business Outcomes A Meta-Analysis. Journal of Applied Psychology, 87(2), 268279. https://doi.org/10.1037/0021-9010.87.2.268

Hastings, S. (2011). The Moderating Effect of Reciprocity Beliefs on Work Outcomes. The University of Western Ontario. 
Retrieved from https://ir.lib.uwo.ca/etd/277

Jenaro, C., Flores, N., Orgaz, M. B., \& Cruz, M. (2011). Vigour and Dedication in Nursing Professionals: Towards a better Understanding of Work Engagement. Journal of Advanced Nursing, 67(4), 865-875. https://doi.org/doi:10.1111/j.1365-2648.2010.05526.x

Kahn, W. A. (1990). Psychological Conditions of Personal Engagement and Disengagement at Work. Academy of Management Journal, 33(4), 692-724. https://doi.org/10.2307/256287

Konovsky, M. A. (2000). Understanding Procedural Justice and its Impact on Business Organizations. Journal of Management, 26(3), 489-511. https://doi.org/10.1016/S0149-2063(00)00042-8

La Motte, S. (2015). Employee engagement depends on what happens outside of the office. Harvard Business Review. Hbr. Org [January 13, 2015].

Ladd, D., \& Henry, R. A. (2000). Helping Coworkers and Helping the Organization: The Role of Support Perceptions, Exchange Ideology and Conscientiousness. Journal of Applied Social Psychology, 30(10), $2028-2049$. https://doi.org/10.1111/j.1559-1816.2000.tb02422.x

Lawrence, L. A. (2011). Work Engagement, Moral Distress, Education Level, and Critical Reflective Practice in Intensive Care Nurses. Nursing Forum, 46(4), 256-268. https://doi.org/doi:10.1111/j.1744-6198.2011.00237.x

Lin, C. (2007). To Share or not to Share: Modeling Knowledge Sharing Using Exchange Ideology as a Moderator. Personnel Review, 36(3), 457-475. https://doi.org/10.1108/00483480710731374

Lu, C., Siu, O., Chen, W., \& Wang, H. (2011). Family Mastery Enhances Work Engagement in Chinese Nurses: A CrossLagged Analysis. Journal of Vocational Behavior, https://doi.org/https://doi.org/10.1016/j.jvb.2010.07.005

Maslach, C., Schaufeli, W. B., \& Leiter, M. P. (2001). Job Burnout. Annual Review of Psychology, 52(1), $397-422$. https://doi.org/10.1146/annurev.psych.52.1.397

Meyer, J. P., Gagné, M., \& Parfyonova, N. M. (2010). Toward an Evidence-based Model of Engagement: What We Can Learn from Motivation and Commitment Research. In S. L. Albrecht (Ed.), Handbook of Employee Engagement. Cheltenham, UK: Edward Elgar Publishing. https://doi.org/10.4337/9781849806374.00011

Molm, L. D. (1994). Dependence and Risk: Transforming the Structure of Social Exchange. Social Psychology Quarterly, 57(3), 163-176. https://doi.org/10.2307/2786874

Molm, L. D., \& Takahashi, N. (2018). In the Eye of the Beholder : Procedural Justice in Social Exchange Author ( s ): Linda D . Molm, Gretchen Peterson and Nobuyuki Takahashi Source : American Sociological Review , Vol . 68 , No . 1 ( Feb ., 2003 ), pp . 128-152 Published by: American Soci, 68(1), $128-152$. https://doi.org/10.2307/3088905

Orpen, C. (1994). The Effects of Exchange Ideology on the Relationship Between Perceived Organizational Support and Job Performance. The Journal of Social Psychology, 134(3), $407-408$. https://doi.org/10.1080/00224545.1994.9711749

Othman, N., \& Nasurdin, A. M. (2013). Social Support and Work Engagement: A Study of Malaysian Nurses. Journal of Nursing Management, 21(8), 1083-1090. https://doi.org/doi:10.1111/j.1365-2834.2012.01448.x

Palmer, B. (2011). Review: Existential Fulfilment, Workload and Work Engagement Among Nurses. Journal of Research in Nursing, 16(5), 480-481. https://doi.org/doi.org/10.1177/1744987110383355

Pazy, A., \& Ganzach, Y. (2010). Predicting Committed Behavior: Exchange Ideology and Pre-entry Perceived Organisational Support. Applied Psychology, 59(2), 339-359. https://doi.org/10.1111/j.1464-0597.2009.00393.x

R Core Team. (2018). R: A Language and Environment for Statistical Computing. $R$ Foundation for Statistical Computing. Vienna, Austria. Retrieved from http://www.r-project.org/

Redman, T., \& Snape, E. (2005). Exchange Ideology and Member-Union Relationships: An Evaluation of Moderation Effects. Journal of Applied Psychology. Snape, Ed: Department of Management and Marketing, The Hong Kong Polytechnic University, Hung Hom, Kowloon, Hong Kong, China, msedward@polyu.edu.hk: American Psychological Association. https://doi.org/10.1037/0021-9010.90.4.765

Revelle, W. (2018). psych: Procedures for Psychological, Psychometric, and Personality Research. Northwestern University. Evanston, Illinois, US. Retrieved from https://cran.r-project.org/package=psych

Rich, B. L., Lepine, J. A., \& Crawford, E. R. (2010). Job Engagement: Antecedents and Effects on Job Performance. Academy of Management Journal, 53(3), 617-635. https://doi.org/10.5465/amj.2010.51468988

Richman, A. (2006). Everyone Wants an Engaged Workforce How Can You Create It. Workspan, 49(1), 36-39.

Rickard, G., Lenthall, S., Dollard, M., Opie, T., Knight, S., Dunn, S., ... Brewster-Webb, D. (2012). Organisational Intervention to Reduce Occupational Stress and Turnover in Hospital Nurses in the Northern Territory, Australia. Collegian, 19(4), 211-221. https://doi.org/https://doi.org/10.1016/j.colegn.2012.07.001

Rosseel, Y. (2012). lavaan: An R Package for Structural Equation Modeling. Journal of Statistical Software, 48(2), 1-36. Retrieved from https://www.jstatsoft.org/article/view/v048i02

Saks, A. M. (2006). Antecedents and Consequences of Employee Engagement. Journal of Managerial Psychology, 21(7), 600-619. https://doi.org/10.1108/02683940610690169

Schaufeli, W. B., \& Bakker, A. B. (2010). Defining and Measuring Work Engagement: Bringing Clarity to the Concept. In A. B. Bakker \& M. P. Leiter (Eds.), Work Engagement: A Handbook of Essential Theory and Research (pp. 
10-24). New York, NY, US: Psychology Press, Taylor \& Francis Group. https://doi.org/10.4324/9780203853047

Schaufeli, W. B., Bakker, A. B., \& Salanova, M. (2006). The Measurement of Work Engagement With a Short Questionnaire: A Cross-National Study. Educational and Psychological Measurement, 66(4), 701-716. https://doi.org/10.1177/0013164405282471

Schaufeli, W. B., Salanova, M., González-Romá, V., \& Bakker, A. B. (2002). The Measurement of Engagement and Burnout: A Two Sample Confirmatory Factor Analytic Approach. Journal of Happiness Studies: An Interdisciplinary Forum on Subjective Well-Being, 3(1), 71-92. https://doi.org/10.1023/A:1015630930326

Scott, B. A., \& Colquitt, J. A. (2007). Are Organizational Justice Effects Bounded by Individual Differences? An Examination of Equity Sensitivity, Exchange Ideology and the Big Five. Group \& Organization Management, 32(3), 290-325. https://doi.org/10.1177/1059601106286877

Shaw, K. (2005). An Engagement Strategy Process for Communicators. Strategic Communication Management, 9(3), 2629.

Shuck, B. (2011). Integrative Literature Review: Four Emerging Perspectives of Employee Engagement: An Integrative Literature Review. Human Resource Development Review, 10(3), 304-328. https://doi.org/10.1177/1534484311410840

Simpson, P. A., \& Kaminski, M. (2007). Gender, Organizational Justice Perceptions and Union Organizing. Employee Responsibilities and Rights Journal, 19(1), 57-72. https://doi.org/10.1007/s10672-006-9032-9

Sinclair, R. R., \& Tetrick, L. E. (1995). Social Exchange and Union Commitment: A Comparison of Union Instrumentality and Union Support Perceptions. Journal of Organizational Behavior, 16(S1), 669-680. https://doi.org/10.1002/job.4030160706

Sze, C. C., \& Angeline, T. (2011). Engaging Employees to Their Jobs : Role of Exchange Ideology as a Moderator. African Journal of Business Management, 5(10), 3986-3994. https://doi.org/10.5897/AJBM11.215

Takeuchi, R., Yun, S., Nason, E. M., \& Wang, X. M. (2007). The "Social” Aspect of Social Exchange Relationship: The Roles of Relational Exchange Ideology. In 67th Annual Meeting of the Academy of Management. Philadelphia, PA, US.

Takeuchi, R., Yun, S., \& Wong, K. F. E. (2011). Social Influence of a Coworker: A Test of the Effect of Employee and Coworker Exchange Ideologies on Employees' Exchange Qualities. Organizational Behavior and Human Decision Processes, 115(2), 226-237. https://doi.org/10.1016/J.OBHDP.2011.02.004

Tomic, M., \& Tomic, E. (2011). Existential Fulfilment, Workload and Work Engagement Among Nurses. Journal of Research in Nursing. https://doi.org/10.1177/1744987110383353

Van Bogaert, P., Clarke, S., Willems, R., \& Mondelaers, M. (2013). Staff Engagement as a Target for Managing Work Environments in Psychiatric Hospitals: Implications for Workforce Stability and Quality of Care. Journal of Clinical Nursing, 22(11-12), 1717-1728. https://doi.org/10.1111/j.1365-2702.2012.04341.x

Walker, A., \& Campbell, K. (2013). Work Readiness of Graduate Nurses and The Impact on Job Satisfaction, Work Engagement and Intention to Remain. Nurse Education Today. https://doi.org/10.1016/j.nedt.2013.05.008

Wayne, S. J., Shore, L. M., \& Liden, R. C. (1997). Perceived Organizational Support And Leader-Member Exchange: A Social Exchange Perspective. Academy of Management Journal, 40(1), 82-111. https://doi.org/10.5465/257021

Witt, L. A. (1991). Exchange Ideology as a Moderator of Job Attitudes-Organizational Citizenship Behaviors Relationships. Journal of Applied Social Psychology, 21(18), 1490-1501. https://doi.org/10.1111/j.15591816.1991.tb00483.x

Witt, L. A. (1992). Exchange Ideology as a Moderator of the Relationships Between Importance of Participation in Decision Making and Job Attitudes. Human Relations, 45(1), $73-85$. https://doi.org/10.1177/001872679204500104

Witt, L. A., \& Broach, D. (1993). Exchange Ideology as a Moderator of the Procedural Justice-Satisfaction Relationship. The Journal of Social Psychology, 133(1), 97-103. https://doi.org/10.1080/00224545.1993.9712122

Witt, L. A., Kacmar, K. M., \& Andrews, M. C. (2001). The interactive effects of procedural justice and exchange ideology on supervisor-rated commitment. Journal of Organizational Behavior, 22(5), 505-515. https://doi.org/10.1002/job.099

Xiao, Y., Zhang, X., \& Ordóñez de Pablos, P. (2017). How does Individuals' Exchange Orientation Moderate the Relationship Between Transformational Leadership and Knowledge Sharing? Journal of Knowledge Management, 21(6), 1622-1639. https://doi.org/10.1108/JKM-03-2017-0120 